\title{
COVID-19 Pandemic Crisis: The Recovery Strategy of Hotel Business in Bengkulu City Through Adoption New-normal
}

Rajiv Dharma Mangruwa, Akbariah Mohd Mahdzir, Nur Naha Abu Mansor

To Link this Article: http://dx.doi.org/10.6007/IJARBSS/v11-i9/11252

DOI:10.6007/IJARBSS/v11-i9/11252

Received: 08 July 2021, Revised: 10 August 2021, Accepted: 30 August 2021

Published Online: 29 September 2021

In-Text Citation: (Mangruwa et al., 2021)

To Cite this Article: Mangruwa, R. D., Mahdzir, A. M., \& Mansor, N. N. A. (2021). COVID-19 Pandemic Crisis: The Recovery Strategy of Hotel Business in Bengkulu City Through Adoption New-normal. International Journal of Academic Research in Business and Social Sciences, 11(9), 1764-1777.

\section{Copyright: @ 2021 The Author(s)}

Published by Human Resource Management Academic Research Society (www.hrmars.com)

This article is published under the Creative Commons Attribution (CC BY 4.0) license. Anyone may reproduce, distribute, translate and create derivative works of this article (for both commercial and non-commercial purposes), subject to full attribution to the original publication and authors. The full terms of this license may be seen at: http://creativecommons.org/licences/by/4.0/legalcode

Vol. 11, No. 9, 2021, Pg. 1764 - 1777

Full Terms \& Conditions of access and use can be found at http://hrmars.com/index.php/pages/detail/publication-ethics 


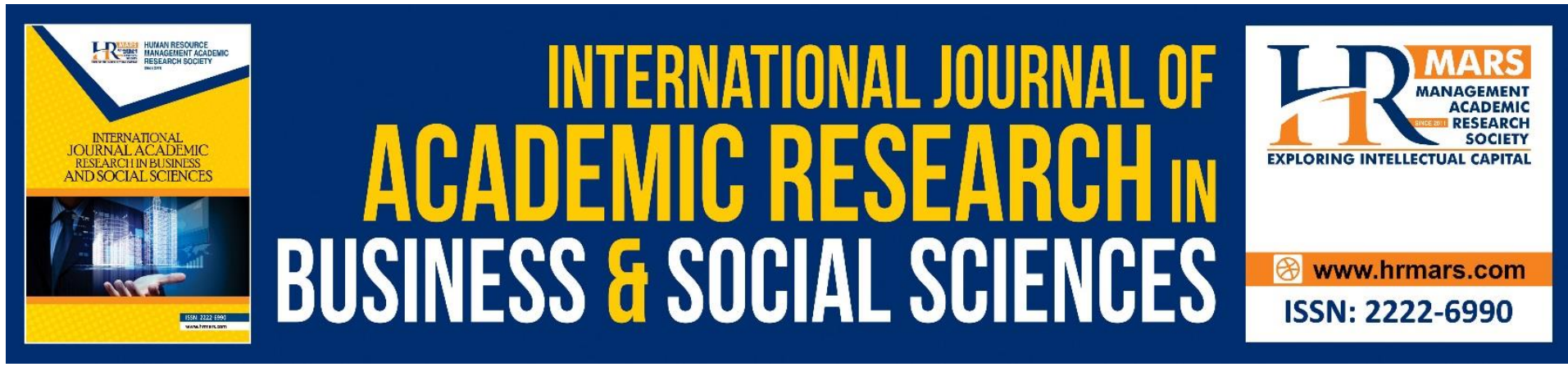

\title{
COVID-19 Pandemic Crisis: The Recovery Strategy of Hotel Business in Bengkulu City Through Adoption New-normal
}

\author{
Rajiv Dharma Mangruwa \\ Azman Hashim International Business School (AHIBS)- University of Technology Malaysia \\ (UTM), Malaysia, Faculty of Communication and Business-Telkom University, Indonesia \\ Bandung, Indonesia \\ Email: rmangruwa@telkomuniversity.ac.id
}

Akbariah Mohd Mahdzir

Malaysia Japan International Institute of Technology, University of Technology Malaysia (UTM), Malaysia, Kuala Lumpur, Malaysia

Email: akbariah.kl@utm.my

Nur Naha Abu Mansor

Azman Hashim International Business School (AHIBS), University of Technology Malaysia

(UTM), Malaysia, Kuala Lumpur, Malaysia

Email: nurnaha@utm.my

\begin{abstract}
The pandemic has had a worldwide economic impact. During the turbulent period in Indonesia, Bengkulu's gross domestic product (GRP) was the lowest in Sumatra in 2020. During the pandemic COVID-19 crisis, it is essential to investigate hotel business recovery strategies in Bengkulu. The purpose of this study is to determine the level of customer satisfaction in TripAdvisor's adaptation to new-normal conditions, as well as how business hotels used the COVID-19 standard operating procedures (SOPs) policy at City hotels in Bengkulu. The study employed the content analysis technique, which was carried out by evaluating 302 TripAdvisor reviews and was followed by first-hand observations of a selection of hotel businesses in Bengkulu. The study's findings reveal that the client is pleased with the improvements, and the hotel followed the standard COVID-19 practice of wearing masks, washing hands, and keeping a safe distance. According to the findings of this study, the government should put its faith in hotel operators whose local communities are affected by the rules that have been enacted.
\end{abstract}

Keywords: Pandemic, COVID-19, Recovery Strategy, Hotel Business

Introduction

The COVID-19 pandemic has had an impact on global social and economic life. Tourism is one of the sectors most affected by the COVID-19 pandemic. Travel policy restrictions significantly 
reduce supply and demand for domestic and international tourism (Gössling et al., 2020). Based on the UNWTO report until the June 2020 period, it was estimated that foreign tourist arrivals decreased by $93 \%$ or lost 440 million visitors compared to June 2019 YoY. Hugely the lost USD 460 million estimated revenue from the tourism sector, which caused the worst period in global tourism development since 1950 (Dastgerdi et al., 2021). On a country level, the pandemic has hit the Indonesian economy tremendously. The decline occurred in almost all economic sectors, which caused a contraction in economic growth in the second quarter of $5.32 \%$ (y-o-y) and $4.19 \%$ (q-to-q) (bps.go.id, 2021). Business continuity experienced the most significant contraction during this pandemic, which was the tourism sector, which was represented by a decline in the transportation and warehousing business fields as well as the provision of accommodation and food and drank by $-30.84 \%$ and $-22.02 \%$ (bps.go.id, 2021).

Bengkulu is a city in Indonesia located at latitude 2016'3031 LS and longitude 10101'103041 BT on the western coast of the island of Sumatra (Herlin \& Yati, 2019). Bengkulu City has a land area of $152.00 \mathrm{~km} 2$ and a population of 371,828 people in 2020 . The pandemic has a sizeable worldwide impact, and Bengkulu is not immune. According to the Central Bureau of Statistics (BPS), Bengkulu Province's economic growth in the fourth quarter of 2020 remained decreased or -2.39 percent when compared to the same time the previous year (YoY) owing to the COVID-19 pandemic (Azhar, 2021). As part of the economic situation and contribution, the hotel industry is helping to sustain Bengkulu's gross domestic product (GRP), which is the lowest in Sumatra at IDR 72,143 per capita (bps.go.id, 2021). The economic instability with the innovation protocol standard is driving the creative economy of the people surrounding it. To generate good evaluations during the pandemic crisis, hoteliers must work with the tour and online travel brokers to promote events and tourist attractions worth visiting.

Bengkulu municipal regulation for large-scale social restrictions (PSBB) from Governor of Bengkulu number 22nd in the year 2020 concerns the application of discipline and enforcement of health protocol laws to prevent and control coronavirus disease (Govenor, 2020). The impact on the hotel industry was significant, necessitating a temporary closure from April to June 2020 (Kominfo, 2020). The impact has resulted in a drop in the occupancy rate of hotel rooms to continue their commercial activities as a result of diminished interest and purchasing power of hotel business customers. This is critical in anticipating the sustainability of the hotel sector for the Bengkulu City Government for economic pillars and economic growth at poverty reduction worldwide in 2030(Murniningtyas \& Endah, 2018). One of the ideas is to apply the COVID-19 protocol in company operations and to obtain online ratings of hotels in Bengkulu that cater to clients during the epidemic (Farmaki et al., 2020).

During a pandemic, online reviews provide a vital chance for businesses to be customercentric by giving essential information required for a hotel (Yacoub \& ElHajjar, 2021). According to one research (Mayer, 2015), the role of online travel review titles is comparable to that of newspaper headlines or advertising slogans. The title summarizes the consumer's travel experience and impacts how customers estimate review material based on the title (Baka, 2016). Customer satisfaction levels during a pandemic are crucial to assess. Thus, online reviews on the internet platform are critical to be investigated. Customer satisfaction will need to be improved the performance of hotel business services in Bengkulu. Therefore, it is critical to understand the recovery strategy of the hotel sector to ensure business continuity according to the Government regulation. As a result, this research is crucial in 
analyzing the collaborative approach adaption for the stakeholder during the new normal COVID-19 pandemic. This study's contribution will be to make recommendations and guidelines for the hospitality industry in Bengkulu.

\section{Literature Review}

\section{The Sustainability of the Hospitality Industry}

The pandemic has caused a worldwide tourism sector crisis (loannides \& Gyimóthy, 2020). Although the study has described the impact of the coronavirus, which has become a global adversary due to the lack of a vaccine that is 100 percent effective and limited medical capacity to treat diseases, non-medical activities are the primary approach to combat the pandemic. One of them is through global travel restrictions and the recommendation to stay at home, which resulted in the worst economic growth since World War II, affecting more than 90 percent of the world's population by preventing public gatherings, community mobility, and tourism activities, which mostly ceased in March 2020. During this epidemic, the function of the online review of electronic word of mouth (eWOM) as a reference to whether the consumer will place an order through the preferred lodging location is essential (Litvin et al., 2008).

Litvin et al (2008) defined eWOM as informal communication addressed to consumers via Internet-based technology connected to evaluating the features of products and services used as an information and reference resources. Electronic word of mouth (Sigala, 2020) has become crucial in viral marketing in the Internet era, and the effect of social responsibility goals during the pandemic crisis has led to references and benchmarks, such that it has become a trend in selecting a choice (Hassan \& Soliman, 2021). Bengkulu is one of the cities in Indonesia that the hotel sector has seriously impacted.

In Bengkulu, the impact of the crisis on the hospitality industry has resulted in a drop in hotel income and government restrictions forcing the hotel to halt operations (Kominfo, 2020) temporarily. Given the best practice during the spread of SARS, avian influenza, and the H1N1 pandemic influencing the reduction in foreign arrivals to Indonesia, particularly Bengkulu city, the Bengkulu administration wants to increase internal tourism as a short-term recovery. Meanwhile, the industry must resurrect the business to generate income through sales. The customer experience and online reviews explain how the business operation has implemented the COVID-19 protocol standard to attract customers. Reviews give extra information about the product from the user's point of view, such as product new traits, characteristics, and COVID-19 standard operating performance. In contrast, suggestion reviews include either good (praise) or negative criticism of the hotelier's service (Wen et al., 2020).

\section{Application of SOP COVID-19}

Governor Regulation Number 22 of 2020 concerning Procedures for Implementing Discipline and Law Enforcement of Health Protocols for the Prevention and Control of COVID-19 regulates the implementation and standards of health protocols in all fields (Governor of Bengkulu, 2020). The continuity of business operations against the COVID-19 protocol regulations is a challenge to be applied with a people's economy through a management approach to the company's internals, especially in continuous improvement. Employees are 
obliged to wear masks while going outdoors and wash their hands in easily accessible areas. It manages to keep a distance in the hotel (Mufti, 2020).

The City hotel is located in an urban location that is commonly utilized by the public for shortterm stays. City hotels are sometimes known as transit hotels since they are typically occupied by business people who use their business services and amenities for a short period. The classification of three-star city hotels with the hotel provisions is based on their class. The authors discovered three 3-4-star city hotels in Bengkulu: Santika Bengkulu, Sinar Sport Hotel Bengkulu, and Mercure Bengkulu. It contains 30 standard rooms, two suite-type rooms, AC, TV, Wifi, separate bathroom and toilet, and sports and games facilities. These facilities and the review will show on TripAdvisor (Chen \& Xie, 2013; Mohammed et al., 2014).

TripAdvisor is an internet platform that provides information on hotel reviews written by travelers. Visitors who have been at the hotel may use TripAdvisor to put down their experiences so that prospective tourists who see the review will be interested in staying at the hotel in question. During pandemics, TripAdvisor Popularity was utilized to determine how customer reviews helped hoteliers recognize the value of good evaluations and the negative influence reviews had on this hotel's reputation. To plan their vacation, more than half of travelers (57.8 percent) check internet reviews. During a pandemic, online reviews of the hotel company are essential in business operations to ensure safety during a hotel stay (Hall et al., 2020). Even though TripAdvisor has 150 million reviews, adopting a safety procedure from the hotel industry in the city of Bengkulu would be beneficial in investigating their vacation experiences and expressing themselves throughout the pandemic.

\section{Methods}

This study employs both primary data and a qualitative descriptive method and secondary data and a case study technique. A qualitative research design is a broad research strategy that is defined, flexible, and may alter or experience development and refinement simultaneously during the research process (Dr. Ibrahim, 2015). The principal data source came from the findings of content analysis on online customer reviews on study items based on TripAdvisor.

Table 1. Object of The Research

\begin{tabular}{|l|l|l|l|}
\hline No & Hotel & $\begin{array}{l}\text { Ranking of hotel in } \\
\text { TripAdvisor } \\
\text { website }\end{array}$ & Addres \\
\hline 1 & $\begin{array}{l}\text { Sinar Sport } \\
\text { Hotel } \\
\text { Bengkulu }\end{array}$ & 1 st & $\begin{array}{l}\text { Jl. Letjend Soeprapto no. 378 Ratu Samban, Bengkulu } \\
38222 \text { Indonesia }\end{array}$ \\
\hline 2 & $\begin{array}{l}\text { Hotel } \\
\text { Santika } \\
\text { Bengkulu }\end{array}$ & 2 nd & Jln. Jati No. 45 Sawah Lebar, Bengkulu 38228 Indonesia \\
\hline 3 & $\begin{array}{l}\text { Mercure } \\
\text { Bengkulu }\end{array}$ & $3 r d$ & $\begin{array}{l}\text { Jl. S. Parman No.27 Padang Jati, Ratu Samban, Bengkulu } \\
38227 \text { Indonesia }\end{array}$ \\
\hline
\end{tabular}

Source: TripAdvisor (2021) 
Secondary data emphasizes the socially constructed nature of reality, the close link between the researcher and the topic under investigation, emphasizes value-laden nature, and attempts to discover answers to concerns about how social experiences originate as well as their meaning (Breier et al., 2021). Because this research was only done in a few hotels, it cannot be termed a collective case study that looks at more prevalent instances. According to table 1, the population in this study consisted of two hotels in Bengkulu, as obtained through the TripAdvisor web platform in April 2021. The sample was chosen using nonprobability sampling and purposive sampling, with the object selection based on the first to third hotel ranking category from the TripAdvisor website, from a total of 36 hotels on the TripAdvisor website, so that three hotels were sampled or the object of this research, as shown in Table 1, and are located in the city of Bengkulu.

\section{Data Collection}

Table 2. Hotel Business Online Review

\begin{tabular}{|l|l|l|l|l|l|}
\hline Hotel & Excellent & $\begin{array}{l}\text { Very } \\
\text { Good }\end{array}$ & Average & Poor & Terrible \\
\hline Santika & 21 & 71 & 25 & 2 & 2 \\
\hline $\begin{array}{l}\text { Sinar } \\
\text { Sport }\end{array}$ & 111 & 41 & 15 & 1 & 1 \\
\hline Mercure & 9 & 6 & 1 & 1 & 0 \\
\hline
\end{tabular}

Source: TripAdvisor (2021)

According to Table 2, there are 304 consumer reviews on TripAdvisor. According to Table 2, the online rating system on TripAdvisor is divided into five categories: excellent, excellent, average, poor, and dreadful. Because consumers may evaluate the length of their stay at a hotel and offer an evaluation review of a hotel, ratings are the outcome of a credible assessment for research. According to one research (Jiang \& Wen, 2020), positive ratings in the "great" category are defined as reviews that demonstrate contentment, while negative reviews in the "awful" category are defined as reviews that show discontent. This study solely used negative and positive TripAdvisor reviews. This study solely used negative and positive TripAdvisor reviews. Table 2 shows the total number of reviews representing customer satisfaction with the excellent category on the TripAdvisor site, totaling 136 reviews. In contrast, the total number of reviews representing dissatisfaction with the TripAdvisor site's terrible category is three, based on data collected in April 2021.

This study employs content analysis techniques to ascertain hotel guests' answers by using the standard COVID-19 procedure. Content analysis is a qualitative research strategy and method that uses text as the topic of study or the unit to be studied to determine the meaning or content of the information delivered (Ibrahim, 2015). Content analysis is used to investigate and develop conclusions about a phenomenon by employing printed and electronic materials with content. In this study, content analysis is carried out in five phases. The initial step is to identify the text to be analyzed, which is TripAdvisor reviews. The second stage is identifying the fascinating, unique, unusual, or controversial content, i.e., a review that only falls under the new normal category. The third stage is to classify the text to discover the elements that cause pleasure and discontent based on prior studies. The fourth stage is to categorize visitor reviews, in which the author verifies how to apply the procedure directly to each hotel. The fifth stage is to analyze, interpret, and make conclusions from the review verification findings. 


\section{Results and Discussion}

\section{Customer level Satisfaction Reviews}

An online review can aid in the continuity of the hotel company in the event of a pandemic by allowing it to adjust to existing regulations. The variety of reactions to business continuity with unforeseen events results in unpredictable outcomes. Customer review requirements might result in fast strategy formulations to address or mitigate the consequences of risks. In this study, researchers examined guest reviews of three research objects: Santika Bengkulu, Sinar Sport Hotel Bengkulu, and Mercure Bengkulu, all of which are 3-4 star city hotels in the city of Bengkulu (Tian, 2013).

Table 3. Online Hotel Satisfaction Rate

\begin{tabular}{|l|l|l|l|l|}
\hline Hotel & Platform & Satisfy & dissatisfied & Rating \\
\hline $\begin{array}{l}\text { Santika } \\
\text { Hotel } \\
\text { Bengkulu }\end{array}$ & TripAdvisor & 21 & 2 & $4.0 / 5.0$ \\
\hline $\begin{array}{l}\text { Sinar } \\
\text { Sport } \\
\text { Hotel } \\
\text { Bengkulu }\end{array}$ & TripAdvisor & 111 & 1 & $4.5 / 5.0$ \\
\hline $\begin{array}{l}\text { Mercure } \\
\text { Hotel } \\
\text { Bengkulu }\end{array}$ & TripAdvisor & 9 & 0 & $4.5 / 5.0$ \\
\hline
\end{tabular}

Source: TripAdvisor (2021)

An online review can aid in the continuity of the hotel company in the event of a pandemic by allowing it to adjust to existing policies (Hu \& Chen, 2016). The type of reaction to business continuity with unforeseen occurrences that might result in unexpected outcomes that cannot be predicted in the end. Customer review requirements might result in fast strategy formulations to address or mitigate the consequences of risks. In this study, researchers evaluated guest reviews of three research objects: Santika Bengkulu, Sinar Sport Hotel Bengkulu, and Mercure Bengkulu, all 3-4-star city hotels in the city of Bengkulu.

Table 3 summarises the outcomes of assessing the satisfaction and discontent of guest evaluations in nominal and percentage form and overall ratings, which are then used as data in this study. According to the TripAdvisor platform, the Sinar Sport hotel had 170 reviews, with 111 happy or about 99.1 percent and 1 or 0.9 percent dissatisfied, resulting in a 4.5 / 5 overall rating. Santika has 121 reviews, with 21 pleased or 91.5 percent contentment reviews and 2 dissatisfied or 8.6 percent dissatisfaction reviews, with an overall rating of $4.0 / 5$. As a result, Mercure Bengkulu has 17 total reviews, with 9 or $100 \%$ satisfied reviews and 0 or $0 \%$ unsatisfied reviews, for an overall rating of $4.5 / 5$. The contribution to encouraging consumer comment is that the government requires hotel businesses to follow SOP requirements. Even though the research in the consequences and difficulties states (Japutra \& Situmorang, 2021) that hotels should stay loyal to their core brand values rather than generating new offers that stray from the brand promise of low-level service throughout the implementation of COVID19 SOPs. 
Based on TripAdvisor statistics, the online review of customer satisfaction for city hotels in Bengkulu city indicated an acceptable rating of 96.3 percent, despite the circumstances during the pandemic COVID-19 with new-normal conditions and standard procedure implemented. The outcome shows how, throughout the pandemic crisis, the customer could assist the business continuity at hotel Bengkulu City while encouraging the reviewer based on their experience. The positive outcome during the pandemic allowed the researcher to assess that the new adaption model and SOP execution were outstanding and resulted in the highest degree of satisfaction with the pandemic circumstances. Finally, this calculated customer satisfaction based on the overall number of pleased customers that the hotel had used. As a result, it has been demonstrated that establishing an online review system needs extensive preparation and planning to have an entire and successful system that applies the SOP at the hotel operation. All available resources, including internal capabilities, should be considered. As the team will be the core and referral team by top Management and users, internal capabilities will be the key strategy or factor that should be examined before beginning system development. On the other hand, internal capabilities include their knowledge in the specific field to be applied by SOP, such as the front desk, back end, and management team, who should assure the success of the SOP system itself.

\section{The Observation of the implementation of the SOP COVID-19}

The present COVID-19 problem has resulted in a variety of situations in hotels in Bengkulu City. The adaptation to the new-normal conditions, the hotel sector has impacted various services that must be in the face of services provided. It will be fascinating to watch how the regulation standard operations are applied in Bengkulu city hotels. Despite concerns about the hotel industry's future due to the pandemic, the unusual scenario highlighted the underlying potential that might be exploited if restrictions were relaxed. The regulations on the Trip Advisor website for travel safety during COVID-19 must be followed during the stay period: all linens are sanitized in the high-temperature wash, face masks are required for guests in public areas, face masks are required for staff in public areas, floors are marked for social distancing, hand sanitizer is available to guests and staff, and paid stay-at-home options are available (Jiang \& Wen, 2020).

\section{Sinar Sport Hotel Bengkulu}

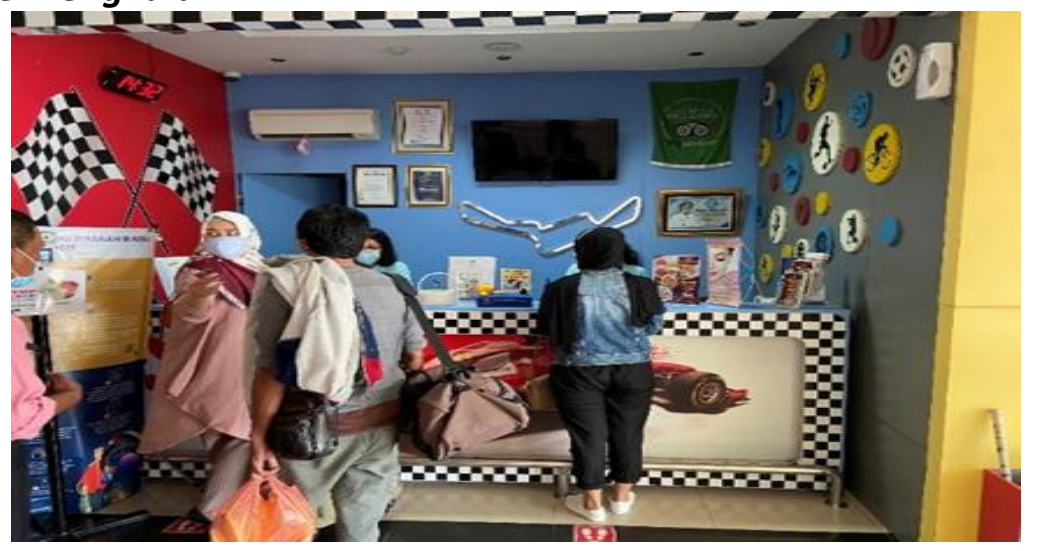

Fig. 1. Investigation of protocol standard in Hotel Sinar Sport

Source: Author's documentation (2021)

The study of the current implementation of the COVID-19 pandemic protocol is most likely to gather information and learnings about how it was implemented in the industry. One 
type of collaboration in its sector is professionalism in adhering to the regulations established by the government. Work professionalism also refers to running a business for profit or as a source of income. As seen in Fig. 1, Wearing masks, washing their hands in easily accessible areas, and keeping a safe distance were all heavily practiced. The reviewer P1 of Hotel Sinar Sport was reflected on the TripAdvisor website.

"Our first visit to Bengkulu City, this hotel is clean and well-used, uses the COVID-19 protocol well and is affordable, this hotel provides good accommodation and good souvenirs".

This perspective is indicative of the TripAdvisor website's identification of customers who stay at business hotels, which then acts as assessment material on hotels that struggle with sustainability and the necessity to keep the business operating and manage their costs regularly. According to the findings of the author's study at the Sinar Sport hotel, industry participants are aware of the possibilities for applying standard operating procedures as new market segmentation and grounds for adding value to the services supplied. The goal of value addition is to preserve company continuity in the face of a pandemic that cannot be expected to terminate. The use of sound systems and procedures, as well as strict hygiene standards, throughout the hotel from check-in to check-out, which includes all stakeholders in tourism, hotel workers, vendors or suppliers, and guests themselves; the availability of supporting equipment such as thermo-guns, trendy masks, and comfortable hand-gloves for the wearer; a promotion that is on target and price anticipation (Hall et al., 2020; Seraphin, 2021).

\section{Santika Hotel Bengkulu}

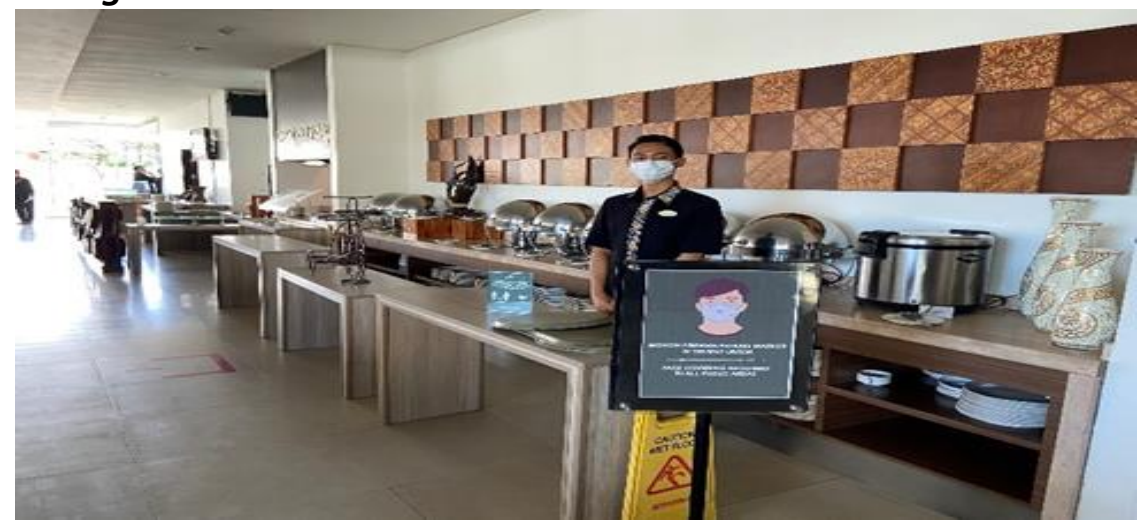

Fig. 2. Investigation of protocol standard in Santika Hotel

Source: Author's documentation (2021)

The hotel's decreasing economic conditions are an attempt to adjust to the newnormal conditions, prompting Management to take actual actions to apply the SOP application COVID-19 to improve the salesroom (Huang et al., 2020). Business continuity to market the hotel to conduct the marketing that refers to the government protocol Bengkulu against the spread of the virus COVID-19, the objective is for all workers to return to work with the application of highly rigorous in operation. The form of businesspeople's efforts in response to government restrictions to limit transmission is to enhance the resilience of the health care system so that the COVID-19 epidemic in the Bengkulu hospitality sector continues to diminish. This stakeholder engagement to combat the epidemic is hugely beneficial in increasing buying power, which has dropped throughout the pandemic. Amid efforts to contain the spread of COVID-19, companies must consider the future and plan for recovery. The inquiry into Santika's business activities was as follows: wear masks while going 
outside, wash their hands in easily accessible areas, and keep a distance $3 \mathrm{M}$ have effectively implemented. On the Tripadvisor website, Santika Hotel reviewer P2 reflected.

"Nice rooms, cold air conditioning while a quite challenge we have to breakfast in a hotel room instead of in the restaurant with limited of choice".

Based on the P2 analysis, the authors believe that companies perceive possibilities to redesign/reorganize their business models based on consumer demands, particularly in the restaurant industry, which strives for cleanliness and full service. Even though this may impact the workers, implementing the COVID-19 standard to the Santika hotel restaurant pays attention to preserving distance even when dining at the restaurant. As shown in Fig 2, the Management pays special attention to the notion of physical distance in a restaurant by providing the opportunity to dine in his bedroom, which is a new-normal type of commitment adopted by the hotel. Santika reduction is a potential that can happen to efficiency, but companies trying to be the wiser search for and use available labor in the new position of proper business continuity management. To adapt to contemporary situations, company stakeholders must realize that hospitality is about delivering service and satisfaction (Ioannides \& Gyimóthy, 2020).

\section{Mercure Hotel Bengkulu}

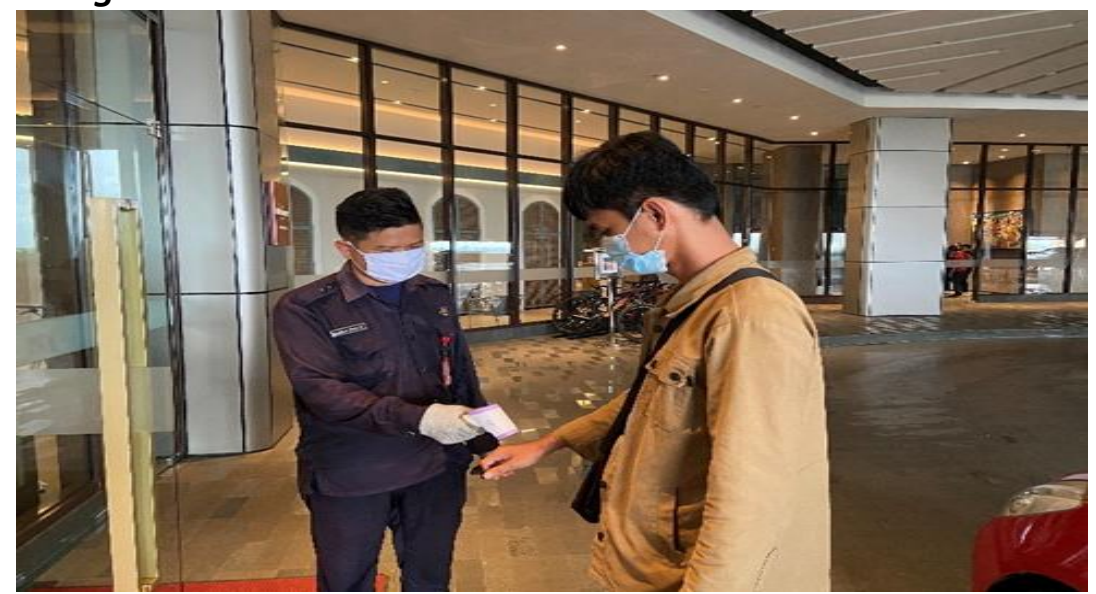

Fig. 3. Investigation of Protocol Standard in Santika Hotel

Source: Author's documentation (2021

With the collaboration of all stakeholders and coordinated responses, the city of Bengkulu will be able to successfully manage this public health emergency, particularly in the afflicted hospitality business. Collaboration between the federal government, provinces, cities, companies, hotel industry groups, universities, people, and the media to halt the spread of the virus, assist sufferers, and combat economic collapse, especially the hotel industry. According to the rule, the business continuity in Mercure was to stress wearing masks while going outdoors, washing their hands in easily accessible areas, and it manages to keep a distance reviewer $\mathrm{P} 3$ reported on the internet.

"During the pandemic, I could not travel as usual. As an Accor Gold member, I gave my parents a surprise anniversary gift. It was the right decision because my parents were happy and liked it. I will also stay at this hotel when the COVID-19 pandemic is over". 
The reviewer's awareness of the health consequences of physical interactions and forecasts is obviously of great importance. Although the replies are connected to consumer demands in the hotel industry, P3 reviewers prepare for a typical holiday in the future. We recognize that, given the scenario and conditions during the pandemic, the use of technology to establish virtual relationships has not yet resulted in optimum customer satisfaction. As shown in Fig 3, the Mercure hotel has adopted a high hygiene standard and provides masks to team members in production and the public area. The usage of masks has been provided as part of the uniform and allows the selection of persons who can enter the building with a Thermo gun to measure the body temperature not exceeding 38 degrees. The investigation from the company operation management has followed Governor order number 22 of 2020 about procedures to wear masks while going outdoors, wash their hands in easily accessible areas, and maintain a distance. Although it was essential to apply for hotel business in the city of Bengkulu, the control of stakeholders should be reviewed to maximize the opportunity via safe and comfortable customer experiences while staying at the hotel. The opportunities and obstacles for implementing the COVID-19 standard for new customary adoption in Indonesia are recommended for further investigation.

\section{Conclusion}

Following the ongoing epidemic, research on the influence of COVID-19 is gaining traction across the world, particularly in Indonesia. The function of customer reviews in how the level of hotel customer satisfaction with the execution of the COVID-19 SOP is exceptionally influential on the continuity of the low occupancy business of visitors in the new digital era (Wajahat \& Mannan, 2020). Based on the discussion above and the findings of the author's study, it is possible to infer that the community, including hotel companies in Indonesia, is presently dealing with the consequences of the COVID-19 virus's propagation, which is a critical phase. However, the hotel's policy of adopting the COVID-19 SOP has borne fruit, with the results of customer reviewers during the pandemic in Indonesia revealing an awe-inspiring satisfaction rate in Bengkulu, with the percentage SinarSport hotel 99.1 percent, Santika Hotel 91.5 percent, and 100 percent satisfied. The demonstrates absolute happiness with the hotel, with an astounding amount of 96.3 percent outstanding satisfaction from Tripadvisor.com evaluations.

This study demonstrates this from the standpoint of a recovery strategy implemented through company operations. The choice of stakeholders to establish a safety policy was a crucial component in adopting the Bengkulu government's SOPs. It is essential to personally see how hotels with positive TripAdvisor evaluations implement this SOP. Observations revealed a considerable shift in cleanliness and sanitation needs that were robust and distinct in each hotel in Bengkulu. Creating a "new normal" for operations is critical to assisting hotels in surviving the COVID-19 epidemic. The author discovered modifications in the operations of employees and guests staying at the Sinar Sport hotel, Hotel Santika Bengkulu, and Hotel Mercure by establishing standard operating procedures such as the usage of masks, measuring body temperature, and keeping distance as an obligation of all parties.

Previous tourism and hospitality studies have examined the hotel business strategy to survive in Bali, including an examination of the policies implemented by the hotel by government laws (Diayudha, 2020). The following recommendations are made for hotel managers: (1) improve with SOP applications that are digital information in check-in checkout services, (2) improve cleanliness in rooms, especially on carpets, room corners, and windows to be sterilized regularly, and (3) giving permission for public amenities such as 
swimming pools, gyms, and places of worship to be used with strict protocols. (4) enhancing door-to-door breakfast services so that they can dine at restaurants (5) launching healthawareness programs and handing out free masks to visitors. Recommendations for further research include challenges in applied SOP, including National Luxury Hotels in Indonesia, where each area has different policies. The research may also be carried out in hotels in other cities such as Jakarta, Bali, and Bandung. Furthermore, the reviewed reviews might have come from various sources, including Traveloka, Expedia, and Booking.com.

\section{References}

Azhar, R. (2021). Ekonomi Bengkulu 2020 Minus. Bengkuluekspress.Com. https://bengkuluekspress.com/ekonomi-bengkulu-2020-minus/

Baka, V. (2016). The becoming of user-generated reviews: Looking at the past to understand the future of managing reputation in the travel sector. Tourism Management, 53, 148162. https://doi.org/10.1016/j.tourman.2015.09.004

bps.go.id. (2021). Statistik Indonesia 2020. 2021. https://www.bps.go.id/publication/2020/04/29/e9011b3155d45d70823c141f/statistikindonesia-2020.html

Breier, M., Kallmuenzer, A., Clauss, T., Gast, J., Kraus, S., \& Tiberius, V. (2021). The role of business model innovation in the hospitality industry during the COVID-19 crisis. International Journal of Hospitality Management, 92, 102723. https://doi.org/10.1016/j.ijhm.2020.102723

Chen, C. C., \& Xie, K. (2013). Differentiation of cancellation policies in the U.S. hotel industry. International Journal of Hospitality Management, 34(1), 66-72. https://doi.org/10.1016/j.ijhm.2013.02.007

Dastgerdi, A. S., De Luca, G., \& Francini, C. (2021). Reforming housing policies for the sustainability of historic cities in the post-covid time: Insights from the atlas world heritage. Sustainability (Switzerland), 13(1), 1-12. https://doi.org/10.3390/su13010174

Diayudha, L. (2020). Industri Perhotelan Di Indonesia Pada Masa Pandemi Covid-19: Analisis Deskriptif. Journal FAME: Journal Food and Beverage, Product and Services, Accomodation Industry, Entertainment Services, 3(1), 41-44.

Dr. Ibrahim. (2015). Penelitian Kualitatif. Journal Equilibrium, 5, 1-8. yusuf.staff.ub.ac.id/files/2012/11/Jurnal-Penelitian-Kualitatif.pdf

Farmaki, A., Miguel, C., Drotarova, M. H., Aleksić, A., Časni, A. Č., \& Efthymiadou, F. (2020). Impacts of Covid-19 on peer-to-peer accommodation platforms: Host perceptions and responses. International Journal of Hospitality Management, 91(August). https://doi.org/10.1016/j.ijhm.2020.102663

Gössling, S., Scott, D., \& Hall, C. M. (2020). Pandemics, tourism and global change: a rapid assessment of COVID-19. Journal of Sustainable Tourism, 0(0), 1-20. https://doi.org/10.1080/09669582.2020.1758708

Govenor. (2020). Regulations Governor of Bengkulu number 22nd the year 2020. http://jdih.bengkuluprov.go.id

Hall, C. M., Scott, D., \& Gössling, S. (2020). Pandemics, transformations and tourism: be careful what you wish for. Tourism Geographies, 22(3), 577-598.

https://doi.org/10.1080/14616688.2020.1759131

Hassan, S. B., \& Soliman, M. (2021). COVID-19 and repeat visitation: Assessing the role of destination social responsibility, destination reputation, holidaymakers' trust and fear arousal. Journal of Destination Marketing and Management, 19(September 2020), 
100495. https://doi.org/10.1016/j.jdmm.2020.100495

Herlin, H., \& Yati, R. T. (2019). Development Strategy Tourism Tikus Island Bengkulu Province With Swot Analysis. AFEBI Management and Business Review, 4(1), 60. https://doi.org/10.47312/ambr.v4i1.230

$\mathrm{Hu}$, Y. H., \& Chen, K. (2016). Predicting hotel review helpfulness: The impact of review visibility, and interaction between hotel stars and review ratings. International Journal of Information Management, 36(6), 929-944. https://doi.org/10.1016/j.ijinfomgt.2016.06.003

Huang, A., Makridis, C., Baker, M., Medeiros, M., \& Guo, Z. (2020). Understanding the impact of COVID-19 intervention policies on the hospitality labor market. International Journal of Hospitality Management, 91(August), 102660. https://doi.org/10.1016/j.ijhm.2020.102660

loannides, D., \& Gyimóthy, S. (2020). The COVID-19 crisis as an opportunity for escaping the unsustainable global tourism path. Tourism Geographies, 22(3), 624-632. https://doi.org/10.1080/14616688.2020.1763445

Japutra, A., \& Situmorang, R. (2021). The repercussions and challenges of COVID-19 in the hotel industry: Potential strategies from a case study of Indonesia. International Journal of Hospitality Management, 95(December 2020), 102890. https://doi.org/10.1016/j.ijhm.2021.102890

Jiang, Y., \& Wen, J. (2020). Effects of COVID-19 on hotel marketing and management: a perspective article. International Journal of Contemporary Hospitality Management, 32(8), 2563-2573. https://doi.org/10.1108/IJCHM-03-2020-0237

Kominfo, B. (2020). Bisnis Hotel di Bengkulu Menuju Normal. Bengkuluprov.Go.Id. https://bengkuluprov.go.id/bisnis-hotel-di-bengkulu-menuju-normal/

Litvin, S. W., Goldsmith, R. E., \& Pan, B. (2008). Electronic word-of-mouth in hospitality and tourism management. Tourism Management, 29(3), 458-468.

https://doi.org/10.1016/j.tourman.2007.05.011

Mayer, N. O. (2015). Online reputations: Why hotel reviews matter and how hotels respond. $P W C$, June.

https://www.pwc.ch/de/publications/2016/pwc_global_hotels_report_2015_e.pdf

Mohammed, I., Guillet, B. D., \& Law, R. (2014). Competitor set identification in the hotel industry: A case study of a full-service hotel in Hong Kong. International Journal of Hospitality Management, 39, 29-40. https://doi.org/10.1016/j.ijhm.2014.02.002

Mufti, R. (2020). Tourism will take at least a year to recover from COVID-19 outbreak: Economists. Www.Thejakartapost.Com.

https://www.thejakartapost.com/news/2020/04/06/tourism-will-take-at-least-a-yearto-recover-from-covid-19-outbreak-economists.html

Murniningtyas, A., \& Endah, S. A. (2018). Tujuan Pembangunan Berkelanjutan di Indonesia: Vol. III (Issue 2).

Seraphin, H. (2021). COVID-19: an opportunity to review existing grounded theories in event studies. Journal of Convention and Event Tourism, 22(1), 3-35. https://doi.org/10.1080/15470148.2020.1776657

Sigala, M. (2020). Tourism and COVID-19: Impacts and implications for advancing and resetting industry and research. Journal of Business Research, 117(June), 312-321. https://doi.org/10.1016/j.jbusres.2020.06.015

Tian, Y. (2013). Engagement in online hotel reviews: A comparative study. Discourse, Context and Media, 2(4), 184-191. https://doi.org/10.1016/j.dcm.2013.10.002 
Wajahat, M., \& Mannan, A. (2020). Munich Personal RePEc Archive The Impact of Marketing Mix and Customer Value on Customer Loyalty The Impact of Marketing Mix and Customer Value on Customer Loyalty. 104683.

Wen, J., Kozak, M., Yang, S., \& Liu, F. (2020). COVID-19: potential effects on Chinese citizens' lifestyle and travel. Tourism Review, March. https://doi.org/10.1108/TR-03-2020-0110

Yacoub, L., \& ElHajjar, S. (2021). How do hotels in developing countries manage the impact of COVID-19? The case of Lebanese hotels. International Journal of Contemporary Hospitality Management, 33(3), 929-948. https://doi.org/10.1108/IJCHM-08-20200814 